\title{
Stimulation of insulin release in isolated rat islets by GIP in physiological concentrations and its relation to islet cyclic AMP content
}

\author{
E. G. Siegel and W. Creutzfeldt \\ Department of Medicine, Division of Gastroenterology and Metabolism, University of Göttingen, Göttingen, FRG
}

\begin{abstract}
Summary. Several insulinotropic hormones have been shown to increase the level of cyclic AMP in isoted islets. This study was performed to investigate whether gastric inhibitory polypeptide (glucose-dependent insulin-releasing polypeptide) has a similar effect, in particular at concentrations close to the physiological level in blood. Collagenase isolated rat islets were maintained for $24 \mathrm{~h}$ in tissue culture (medium 199) and then incubated for $30 \mathrm{~min}$ for measurement of insulin release and cyclic AMP content. Glucose-induced $(16.7 \mathrm{mmol} /$ 1) insulin release was enhanced by gastric inhibitory polypeptide $1-100 \mathrm{ng} / \mathrm{ml}(0.196-19.6 \mathrm{nmol} / 1)$ in a dose-related fashion. The cyclic AMP content was enhanced only by $100 \mathrm{ng} /$ $\mathrm{ml}$. However, when $0.1 \mathrm{mmol} / 1$ of the phosphodiesterase inhibitor 3-isobutyl-1-methylxanthine was present, even $1 \mathrm{ng} /$ $\mathrm{ml}$ of gastric inhibitory polypeptide increased both cyclic
\end{abstract}

AMP content and insulin release. Such a concentration of the hormone can be measured in human blood after a meal. In contrast, in freshly isolated islets no effect of the hormone on glucose-induced insulin release or cyclic AMP content could be detected for concentrations ranging from 1 to $100 \mathrm{ng} / \mathrm{ml}$. These findings demonstrate that the hormone sensitivity of isolated islcts is markedly enhanced by short-term maintenance in tissue culture. The results suggest that an increase in cyclic AMP is seen in response to gastric inhibitory polypeptide and may be causally related to the insulinotropic effect of the hormone.

Key words: Isolated islets, tissue culture, insulin release, cyclic AMP, gastric inhibitory polypeptide, perifusion.

\section{Material and methods}

\section{Preparation of islets and maintenance in tissue culture}

Pancreatic islets were isolated by the collagenase digestion technique [14] from male Wistar rats weighing $180-250 \mathrm{~g}$ (Collagenase from Worthington Biochemical Corp.). The islets were separated from the remaining exocrine tissue by handpicking. Batches of $250-400$ islets were maintained for $24 \mathrm{~h}$ in plastic Petri dishes, $6 \mathrm{~cm}$ diameter (Greiner, Nürtingen, FRG) containing $4 \mathrm{ml}$ tissue culture medium 199 [15] supplemented with 10\% heat-inactivated newborn calf serum (Grand Island Biochemical Corp.), $14 \mathrm{mmol} / 1 \mathrm{NaHCO}_{3}, 400 \mathrm{IU} / \mathrm{ml}$ sodium penicillin $\mathrm{G}, 200 \mu \mathrm{g} / \mathrm{ml}$ streptomycin sulfate, $1 \mathrm{mmol} / 1 \mathrm{~N}$-2-hydroxyethylpiperazine- $\mathrm{N}^{\prime}$-ethane sulfonic acid (Hepes) and a glucose concentration of $8.3 \mathrm{mmol} / 1$. The islets were maintained at $37^{\circ} \mathrm{C}, \mathrm{pH} 7.4$ in an atmosphere saturated with water and gassed with an air- $\mathrm{CO}_{2}$ mixture.

Static incubation for measurement of insulin release and cyclic AMP content

After the maintenance period, the islets were washed twice with a modified Krebs-Ringer bicarbonate buffer (KRB-Hepes) containing $2.8 \mathrm{mmol} / \mathrm{l}$ glucose by centrifugation $(150 \mathrm{~g})$ at room temperature, as described in detail previously [16]. This buffer was also used for the static incubation and contained $5 \mathrm{mmol} / 1 \mathrm{NaHCO}, 1 \mathrm{mmol} / 1 \mathrm{CaCl}_{2}$, $0.2 \%$ bovine serum albumin and, in addition, $10 \mathrm{mmol} / 1 \mathrm{Hepes}$. For the experiment, batches of 10 islets were then incubated for $30 \mathrm{~min}$ at $37^{\circ}$ in $2 \mathrm{ml} \mathrm{KRB-Hepes} \mathrm{containing} \mathrm{the} \mathrm{respective} \mathrm{stimulus.} \mathrm{Flat} \mathrm{bot-}$ tom glass vials were used. Usually, 250 islets were used for one experiment allowing an $n=5$ for each of the test conditions. The experiment was stopped by picking out the islets under the microscope and transferring them immediately into $200 \mu 1$ of boiling acetate buffer $(0.05 \mathrm{~mol} / 1 \mathrm{pH} 6.2)$. The incubation buffer was chilled immediately. tissue culture. 
Insulin release was determined by radioimmunoassay [17] using a rat standard and a guinea pig antiserum raised against beef insulin. The sensitivity of the assay was $0.25 \mathrm{ng} / \mathrm{ml}$, the interassay variance $7.8 \%$ and the intraassay variance $5.6 \%$. When freshly isolated islets were used, experiments were performed within $1 \mathrm{~h}$ after collagenase isolation. ${ }^{125}$ I-Insulin and rat insulin standard were purchased from Behringwerke, Marburg, FRG.

\section{Measurement of islet cyclic AMP content}

After the experiment the islets were boiled for at least $20 \mathrm{~min}$ in $0.05 \mathrm{~mol} / 1$ acetate buffer. Blanks for each of the incubation buffers were treated in the same way. Islet cyclic AMP levels were then determined by radioimmunoassay using a commercially available kit (Becton Dickinson and Co., Heidelberg, FRG) after succinylation of samples and standards according to the method of Cailla et al. [18]. This procedure considerably increases the sensitivity, allowing for the determination of less than $0.88 \mathrm{fmol} / \mathrm{vial}$. This lowest standard was always clearly distinct from the zero binding. Samples were assayed in duplicate; the blanks were always less than $4 \%$ of the measured cyclic AMP content of the islets and not different between the respective incubation buffers; they were therefore not subtracted. Insulin release and cyclic AMP content were always determined for the same batch of islets.

\section{Measurement of gastric inhibitory polypeptide (GIP)}

GIP was measured using a radioimmunoassay described in detail previously [19]. A rabbit antiserum was used raised against porcine GIP. The sensitivity of the assay was $31 \mathrm{pg} / \mathrm{ml}$ and the intra assay variance was $7.9 \%$. The molecular weight of GIP is 5105 , i.e. $1 \mathrm{ng} /$ $\mathrm{ml}=0.196 \mathrm{nmol} / 1$.

\section{Perifusion for measurement of dynamic insulin release}

The islets were perifused using a perifusion system described in detail previously $[15,20]$. In brief, 40 islets were placed in a microchamber (volume $70 \mu \mathrm{l}$ ) and perifused with a flow rate of $1 \mathrm{ml} / \mathrm{min}$ resulting in a turnover of approximately 14 chamber volumes $/ \mathrm{min}$. The perifusate consisted of a KRB buffer containing $1.0 \mathrm{mmol} / 1 \mathrm{Ca}, 0.2 \%$ dialysed bovine serum albumin and $14 \mathrm{mmol} / 1 \mathrm{NaHCO}_{3}$. The buffer was gassed with $95 \% \mathrm{O}_{2}$ and $5 \% \mathrm{CO}_{2}$ which allowed for a constant $\mathrm{pH}$ of 7.4 over the time of perifusion. The dead space of the whole system was $1.5 \mathrm{ml}$, and was always taken into consideration. Four chambers were always used in parallel. Usually, after 30 min of perifusion with a buffer containing glucose $2.8 \mathrm{mmol} / 1$ the islets were exposed to $16.7 \mathrm{mmol} / \mathrm{l}$ glucose for another $40 \mathrm{~min}$. The buffer was then switched back to the buffer containing low glucose. Samples of the effluate were collected every minute, from minute 25 to $\mathrm{min} 80$. These 1 -min samples were assayed for insulin every minute, from $\min 25$ to $\min 40$, and then every 5 th $\min$ until $\min 70$, and, thereafter, again $\min 71,72$, $73,75,77$, and 80 .

\section{Statistics}

Statistical analysis was performed by Student's two-tailed t-test for unpaired data unless stated differently.

\section{Results}

\section{Comparison of fresh and cultured islets in perifusion and static incubation}

As both fresh and 24-h cultured islets were used, dynamic insulin release from the two types of islets was compared in perifusion. Both types of islets exhibited a rather sharp rise in the rate of insulin release starting $1 \mathrm{~min}$ after the exposure to glucose $16.7 \mathrm{mmol} / 1$ (Fig. 1 ). A first peak was reached at $3 \mathrm{~min}$. For freshly isolated islets a slight nadir at $4-5 \mathrm{~min}$ was followed by a rapidly

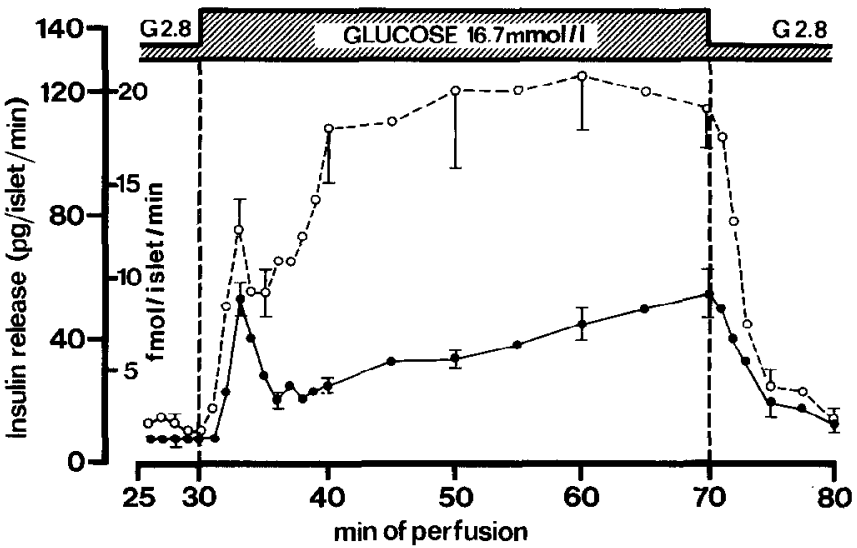

Fig. 1. Dynamic insulin release from freshly isolated and $24 \mathrm{~h}$ cultured islets. Both types of islets were perifused in microchambers for $30 \mathrm{~min}$ with a KRB buffer containing $2.8 \mathrm{mmol} / \mathrm{l}$ glucose and then stimulated for $40 \mathrm{~min}$ with glucose $16.7 \mathrm{mmol} / 1$. They were then exposed to glucose $2.8 \mathrm{mmol} / \mathrm{l}$. Values are means $\pm S E M$, numbers of observations in parentheses; $\mathrm{G}$, glucose; $\mathrm{O}---\mathrm{O} O$ freshly isolated islets $(n=7) ;-24 \mathrm{~h}$ cultured islets $(n=10)$

increasing second phase. For $24 \mathrm{~h}$ cultured islets, a pronounced nadir at 5-7 min was followed by a gradually increasing second phase allowing for the clear distinction of the two phases. Both types of islets returned rapidly to basal release values upon reexposure to the nonstimulating buffer containing $2.8 \mathrm{mmol} / 1$ glucose.

Since in subsequent experiments static incubation was used, the effect of glucose was also compared in fresh and cultured islets in 30-min static incubation. This was performed by pooling the results of a large series of experiments carried out in our laboratory. Basal release $(2.8 \mathrm{mmol} / 1$ glucose $)$ was not different for fresh $(0.41 \pm 0.06 \mathrm{ng} / \mathrm{islet} / 30 \mathrm{~min}, n=53)$ and $24 \mathrm{~h}$ cultured islets $(0.40 \pm 0.04, n=52)$. Glucose $16.7 \mathrm{mmol} / \mathrm{l}$ increased the release of insulin in freshly isolated islets to $1.59 \pm 0.13 \mathrm{ng} /$ islet $/ 30 \mathrm{~min}, n=53$, and to $1.17 \pm 0.05$, $n=52$, in $24 \mathrm{~h}$ cultured islets. Thus, glucose-induced insulin release is slightly less in cultured islets $(p<0.005)$, as in perifusion. However, there is less variance in the results of cultured islets per the SEMs. The insulin content decreased slightly during 24-h tissue culture from $55.8 \pm 6.3 \mathrm{ng}$ /islet, $n=13$ in freshly isolated islets, to $39.5 \pm 1.3, n=4$ after $24 \mathrm{~h}$ culture, the difference being not significant $(p>0.10)$.

\section{Effect of GIP on glucose-induced insulin release and cyclic AMP content in cultured islets}

Insulin release was clearly stimulated by glucose $16.7 \mathrm{mmol} / 1$, from 0.52 to $1.26 \mathrm{ng} /$ islet, $p<0.001$ (Fig. 2). The addition of GIP resulted in a marked potentiation of insulin release. Even a concentration as low as $1 \mathrm{ng} / \mathrm{ml}$ caused a twofold increase $(p<0.02)$. The effect of $16.7 \mathrm{mmol} / \mathrm{l}$ glucose on islet cyclic AMP content was only marginal $(0.05<p<0.10)$. GIP $100 \mathrm{ng} / \mathrm{ml}$ enhanced the cyclic AMP content from $10.8 \pm 0.9$ to $14.1 \pm 1.4 \mathrm{fmol} /$ islet, $p<0.05$. No significant effect on cyclic AMP levels was detected in response to GIP 10 and $1 \mathrm{ng} / \mathrm{ml}$. 

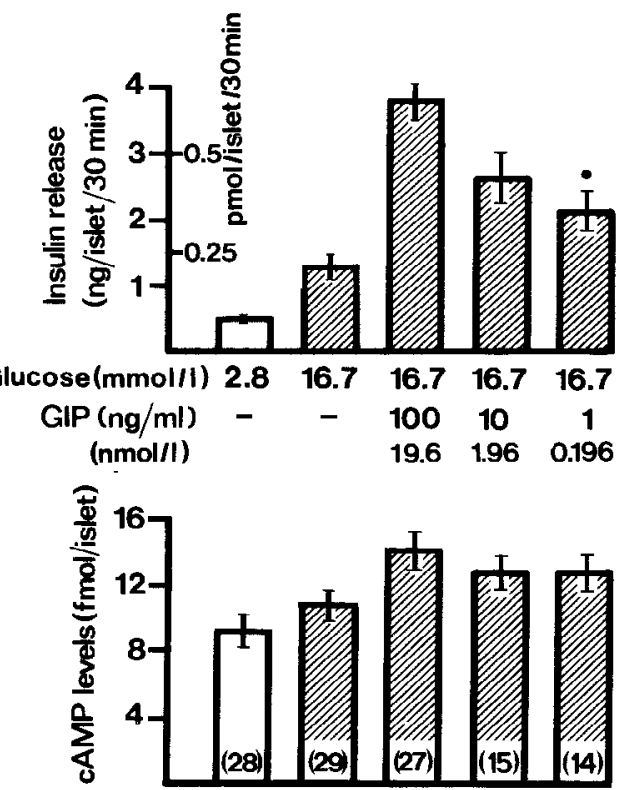

Fig. 2. Effect of GIP on insulin release and cyclic AMP levels in $24 \mathrm{~h}$ cultured islets. Islets were used after 24 -h maintenance in tissue culture. They were then incubated in KRB Hepes buffer for $20 \mathrm{~min}$. Insulin release and cyclic AMP content were always measured on the same batch of 10 islets per vial. Values are means \pm SEM, numbers of observations in parentheses; GIP, gastric inhibitory polypeptide. $1 \mathrm{ng} / \mathrm{ml} \mathrm{GIP}$ is equivalent to $0.196 \mathrm{mmol} / \mathrm{l}$. denotes $p<0.02 \mathrm{vs}$ glucose $16.7 \mathrm{mmol} / 1$ alone

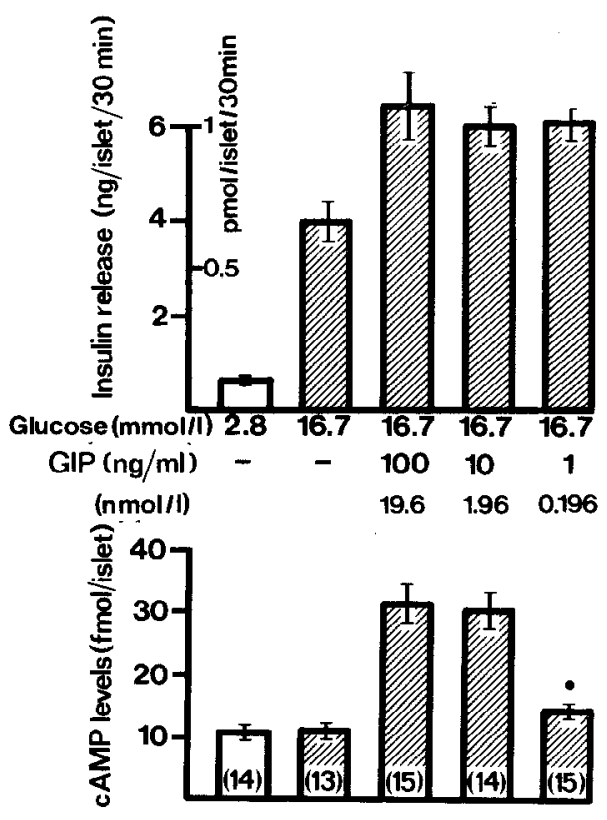

Fig. 3. Effect of GIP on insulin release and cyclic AMP levels in $24 \mathrm{~h}$ cultured islets $(0.1 \mathrm{mmol} / 1$ IBMX present). Experiments were performed like in Figure 2, except that $0.1 \mathrm{mmol} / 1$ of the phosphodiesterase inhibitor 3-isobutyl-1-methylxanthine (IBMX) was present during the $30-\mathrm{min}$ incubation for all conditions. $1 \mathrm{ng} / \mathrm{ml} \mathrm{GIP}$ is equivalent to $0.196 \mathrm{nmol} / \mathrm{l}$. denotes $p<0.05 \mathrm{vs}$ glucose $16.7 \mathrm{mmol} / \mathrm{I}$

As glucose $16.7 \mathrm{mmol} / 1$ had only a marginal influence on islet cyclic AMP content, and a tendency to increase could be seen in most of the experiments, the effect of glucose was investigated in a large series of experiments carried out in our laboratory in part for other purposes. Cyclic AMP content was $7.9 \pm 0.6$ $(n=43)$ for glucose 2.8 and $9.7 \pm 0.8 \mathrm{fmol} /$ islet $(n=43)$ for glucose $16.7 \mathrm{mmol} / \mathrm{l}$, which was again marginal $(0.05<p<0.10)$. Since in almost every experiment (usually $n=5$ for each of the conditions) there was a slight increase, the effect of glucose was also compared on a paired basis always using the mean of one experiment obtained at either 2.8 or $16.7 \mathrm{mmol} / 1$ glucose. For this way of analysis, the incremental effect of $16.7 \mathrm{mmol} / 1$ glucose was $1.85 \pm 0.75(n=9, p<0.05)$, which was significant. At $2.8 \mathrm{mmol} / 1$ glucose, no effect of GIP on insulin release was seen up to $400 \mathrm{ng} / \mathrm{ml}$ (data not shown).

\section{Effect of GIP on glucose-induced insulin release and cyclic AMP content in the presence of IBMX}

As cyclic AMP is rapidly disintegrated by phosphodiesterases, the same protocol as for Figure 2 was employed in the presence of $0.1 \mathrm{mmol} / 1$ of the phosphodiesterase inhibitor 3-isobutyl-1-methylxanthine (IBMX). Results are shown in Figure 3. Consciously, not a high concentration of IBMX was used. Glucose-induced insulin release was clearly enhanced again by all the concentrations of GIP employed ( $p<0.001$ for each of the conditions). GIP also augmented the cyclic AMP content of the islets, with the effect achieving significance even for the lowest concentration employed: GIP $1 \mathrm{ng} / \mathrm{ml}$ increased the cyclic AMP levels from $11.4 \pm 1.0$ to $14.6 \pm$ $1.0 \mathrm{fmol} /$ islet, $p<0.05$.

\section{Effect of IBMX on insulin release and cyclic AMP content}

Comparing Figures 2 and 3 , it might seem as if $0.1 \mathrm{mmol} / 1$ IBMX had no effect on cyclic AMP levels at 2.8 and $16.7 \mathrm{mmol} / 1$ glucose, although a twofold increase is observed when GIP 10 or $100 \mathrm{ng} / \mathrm{ml}$ is present. However, the islets originated from different pools and can, therefore, not be compared. Subsequently, the effects of IBMX were investigated at both low and high glucose in islets originating from the same pool(s) (Table 1). Under such controlled conditions, $0.1 \mathrm{mmol} / 1$ IBMX caused an increase of insulin release and cyclic AMP content both at low and high glucose $(p<0.02$ or less). When in another series of experiments a high concentration of IBMX was tested, these effects were even more pronounced (Table 1 B).

\section{Effect of GIP in freshly isolated islets on insulin release and islet cyclic AMP content}

The experiments shown in Table 2 were carried out on freshly isolated islets in the same fashion as in Figure 2. In freshly isolated islets, $16.7 \mathrm{mmol} / \mathrm{I}$ glucose caused a threefold increase in insulin release and cyclic AMP content after $30 \mathrm{~min}$. No significant effect of GIP could be detected on insulin release or cyclic AMP content. This was also the case when, in a small series, $0.1 \mathrm{mmol} / 1$ IBMX was present in the incubation medium (data not shown). Since this could be due to breakdown of the hormone GIP, its concentration was mea- 
Table 1. Effect of IBMX (3-isobutyl-1-methylxanthine) on insulin release and cyclic AMP levels in 24-h cultured islets

\begin{tabular}{|c|c|c|c|}
\hline & & $\begin{array}{l}\text { Insulin release } \\
\text { (ng/islet } / 30 \mathrm{~min} \text { ) }\end{array}$ & $\begin{array}{l}\text { Cyclic AMP level } \\
\text { (fmol/islet) }\end{array}$ \\
\hline \multirow[t]{4}{*}{ A } & G $2.8 \mathrm{mmol} / 1$ & $0.34 \pm 0.06(13)$ & $8.8 \pm 1.0$ \\
\hline & G $\begin{array}{l}2.8 \mathrm{mmol} / 1+\mathrm{IBMX} \\
0.1 \mathrm{mmol} / 1\end{array}$ & $0.76 \pm 0.12(14)$ & $15.0 \pm 2.0$ \\
\hline & $\mathrm{G} 16.7 \mathrm{mmol} / \mathrm{l}$ & $1.50 \pm 0.12(13)$ & $9.5 \pm 1.1$ \\
\hline & $\begin{array}{c}\mathrm{G} 16.7 \mathrm{mmol} / 1+\mathrm{IBMX} \\
0.1 \mathrm{mmol} / 1\end{array}$ & $4.70 \pm 0.46(14)$ & $21.1 \pm 2.9$ \\
\hline \multirow[t]{4}{*}{ B } & $\mathrm{G} \quad 2.8 \mathrm{mmol} / \mathrm{l}$ & $0.28 \pm 0.06(12)$ & $10.2 \pm 1.1$ \\
\hline & G $\begin{array}{l}2.8 \mathrm{mmol} / 1+\mathrm{IBMX} \\
1 \mathrm{mmol} / 1\end{array}$ & $0.92 \pm 0.10(12)$ & $47.2 \pm 6.2$ \\
\hline & $\mathrm{G} 16.7 \mathrm{mmol} / \mathrm{l}$ & $0.80 \pm 0.12(12)$ & $17.0 \pm 3.1$ \\
\hline & $\begin{array}{l}\mathrm{G} 16.7 \mathrm{mmol} / 1+\mathrm{IBMX} \\
1 \mathrm{mmol} / 1\end{array}$ & $7.10 \pm 0.42(12)$ & $55.0 \pm 6.6$ \\
\hline
\end{tabular}

Islets were incubated after culture in KRB-Hepes buffer for $30 \mathrm{~min}$. Values are presented as mean $\pm S E M$, number of experiments in parentheses. $G$, glucose

Table 2. Effect of GIP on insulin release and cyclic AMP levels in freshly isolated islets after 30 -min incubation

\begin{tabular}{lrc}
\hline & $\begin{array}{l}\text { Insulin release } \\
\text { (ng/islet/30 min) }\end{array}$ & $\begin{array}{l}\text { cyclic AMP } \\
\text { level } \\
\text { (fmol/islet) }\end{array}$ \\
\hline $\mathrm{G} 2.8 \mathrm{mmol} / 1$ & $0.46 \pm 0.03(15)$ & $9.6 \pm 2.2$ \\
$\mathrm{G} 16.7 \mathrm{mmol} / 1$ & $1.45 \pm 0.30(15)$ & $27.5 \pm 2.5$ \\
$\mathrm{G} 16.7 \mathrm{mmol} / 1+\mathrm{GIP} 100 \mathrm{ng} / \mathrm{ml} 1.55 \pm 0.36(14)$ & $25.9 \pm 2.5$ \\
$\mathrm{G} 16.7 \mathrm{mmol} / \mathrm{l}+\mathrm{GIP}$ & $10 \mathrm{ng} / \mathrm{ml} 1.84 \pm 0.39(14)$ & $29.9 \pm 3.0$ \\
$\mathrm{G} 16.7 \mathrm{mmol} / 1+\mathrm{GIP}$ & $1 \mathrm{ng} / \mathrm{ml} 1.67 \pm 0.26(14)$ & $21.3 \pm 2.0^{\mathrm{a}}$ \\
\hline
\end{tabular}

a $p>0.05$ vs $\mathrm{G} 16.7 \mathrm{mmol} / 1$

Islet cAMP content was measured as described in Methods. $1 \mathrm{ng} / \mathrm{ml}$ GIP is equivalent to $0.196 \mathrm{mmol} / 1.1 \mathrm{ng} / \mathrm{ml}$ insulin $=0.17 \mathrm{nmol} / \mathrm{l}$. Values are presented as mean $\pm S E M$, numbers of experiments in parentheses. $\mathrm{G}=$ glucose; $\mathrm{GIP}=$ gastric inhibitory polypeptide.

sured before and after an additional experiment. For the buffer containing the addition of $10 \mathrm{ng} / \mathrm{ml}$, the concentration determined by radioimmunoassay was $14.0 \pm 0.4(n=3)$ before the experiment, $12.1 \pm 0.8$ $(n=3)$ after the experiment and $13.7 \pm 0.9(n=5)$ for incubation vials treated in the same way but without islets. The measured concentration of GIP after the experiment was $104.5 \pm 4.2(n=4)$ when islets were incubated at GIP $100 \mathrm{ng} / \mathrm{ml}$ and $1.02 \pm 0.03(n=5)$ when islets were incubated at $1 \mathrm{ng} / \mathrm{ml}$.

\section{Discussion}

The in vitro maintenance of isolated islets in tissue culture offers several advantages compared to the use of freshly isolated islets. Insulin release is clearly biphasic with a clear nadir separating the two phases (Fig. 1), a pattern very close to the release pattern seen in humans under hyperglycaemic glucose clamp conditions [7] and in the perfused pancreas [8]. Furthermore, such islets can be loaded with isotopes to isotopic equilibrium, e.g. ${ }^{45} \mathrm{Ca}$ [21], facilitating the interpretation of flux studies. Third, the hormone sensitivity after culture has been demonstrated to be increased compared to freshly isolated islets with respect to glucagon [22] and somatostatin [23]. This has been attributed to a possible regeneration of membrane receptors which probably are damaged by the collagenase digestion. With respect to GIP, a striking increase in the hormone sensitivity is seen in the results presented in this study.

Results shown in Figure 2 demonstrate a dose-related increase in glucose-induced insulin release for GIP concentrations between 100 and $1 \mathrm{ng} / \mathrm{ml}$. The lowest concentration is clearly in the physiological range since values of $2 \mathrm{ng} / \mathrm{ml}$ are observed after an oral glucose tolerance $[1,4,7]$ or a mixed meal $[1,5]$. Thus, the hormone sensitivity of these cultured islets is comparable to the in vivo situation. This is in marked contrast to the finding that in freshly isolated islets even the highest GIP concentration had no effect on insulin release. In two previous studies concentrations greater than $1 \mu \mathrm{g} / \mathrm{ml}$ had to be employed $[9,11] ; 1 \mu \mathrm{g} / \mathrm{ml}$ just caused a $5 \%$ increase [9]. In two recent studies, 10 and $15 \mathrm{ng} / \mathrm{ml}$ had stimulatory effects $[10,24]$. Since apparently the GIP concentration surrounding the islets is not altered during the 30 -min incubation, the lack of a stimulatory effect is not due to major breakdown of the hormone. One may, therefore, assume that receptor function is impaired during islet isolation and that the hormone sensitivity can be completely restored by the $24 \mathrm{~h}$ maintenance in tissue culture.

A significant increase in islet cyclic AMP content could only be observed in response to the highest GIP concentration used (Fig. 2). Nevertheless one might expect that also the low GIP concentration should be associated with changes in the adenylate-cyclase cyclic AMP system, since hormones have been shown to act through activation of adenylate cyclase $[12,13]$. This has been reported also for GIP [25]. An effect on cyclic AMP content could have been missed either due to the time course (highest cyclic AMP contents are seen early $[13,22])$, compartmentalization of cyclic AMP and/or activation of phosphodiesterase [12, 13]. Therefore, experiments were also carried out in the presence of the phosphodiesterase inhibitor IBMX. An intermediate concentration of $0.1 \mathrm{mmol} / \mathrm{l}$ was used which under controlled conditions augmented both insulin release and cAMP content (Table 1). As expected, glucose-induced insulin release was clearly enhanced. Under these conditions the lowest concentration of GIP also increased cAMP content apart from stimulating insulin release. In freshly isolated islets, a stimulatory effect on ${ }^{3} \mathrm{H}$-cyclic AMP accumulation and insulin release could only be seen in response to a concentration of approximately $15 \mathrm{ng} / \mathrm{ml}$, whereas $1.5 \mathrm{ng} / \mathrm{ml}$ were ineffective [10].

The lack of a clear stimulatory effect of glucose on cyclic AMP content in these islets contrasts with its marked effect in freshly isolated islets (Table 2). This has been found before [16] and also when ${ }^{3} \mathrm{H}$-cyclic AMP accumulation was measured in the two types of islets in paired conditions [22]. In the present study there was a marginal effect in cultured islets when a large series of experiments was evaluated, the value of 
significance being $p<0.05$ under paired and $0.05<p<$ 0.10 under unpaired conditions. Therefore, an effect of glucose on cAMP content cannot be excluded by the present study; on the other hand, clarification of this point was not the purpose of the study.

The further mechanism of cyclic AMP action on intracellular activation is still a matter of investigation, in particular whether increased cAMP is a primary or secondary event. Calcium ions play an important role and an increase of ionized calcium in the B-cell cytosol is generally thought to be one important step $[12,13,20$, 26]. Agents that increase cAMP like IBMX via phosphodiesterase inhibition or glucagon via activation of adenylate cyclase have both been demonstrated to increase ${ }^{45} \mathrm{Ca}^{++}$efflux $[16,27]$ which may reflect an increase in cytosol $\mathrm{Ca}^{++}$. On the other hand, $\mathrm{Ca}^{++}$with the need of calmodulin activates adenylate cyclase [28, 29]. Certainly, the calcium-calmodulin-cAMP interactions are still a matter of investigation. With respect to this the present study demonstrates that, in vitro, a physiological hormonal stimulus is able to stimulate insulin release at physiological concentrations. The content of one important second messenger, cyclic AMP, is increased.

Acknowledgements. The authors wish to express their gratitude to Ms. K. Bunke and Ms. B. Berning for their excellent technical help. We thank Dr. Ebert, Göttingen, for the determination of GIP. This work was supported by the Deutsche Forschungsgemeinschaft, grant $\mathrm{Si}$ $313 / 1-1$ and Si 313/1-2.

\section{References}

1. Creutzfeldt W (1979) The incretin concept today. Diabetologia 16: $75-85$

2. Siegel EG, Trimble ER, Berthoud H-R, Renold AE (1980) The importance of preabsorptive insulin release on oral glucose tolerance: studies in pancreatic islet transplanted rats. Gut 21: 1002-1009

3. Trimble ER, Berthoud H-R, Siegel FG, Renold AE (1981) Importance of cholinergic innervation of the pancreas for glucose tolerance in the rat. Am J Physiol 241: E337-E341

4. Cataland S, Crockett SE, Brown JC, Mazzaferri EL (1973) Gastric inhibitory polypeptide (GIP) stimulation by oral glucose in man. $\mathbf{J}$ Clin Endocrinol Metab 39: 223-228

5. Ebert R, Creutzfeldt W (1979) Gastric inhibitory polypeptide. Clin Gastroenterol 9: 679-698

6. Brown JC, Dryburgh JR, Ross SA, Dupré J (1975) Identification and actions of gastric inhibitory polypeptide. Recent Prog Horm Res 31: 487-532

7. Elahi D, Andersen DK, Brown JC, Tobas HT, Hcrshcopf J, Raizes GS, Tobin JD, Andres R (1979) Pancreatic $\alpha$ - and $\beta$-cell responses to GIP infusion in normal man. Am J Physiol 237: E185-E191

8. Pederson RA, Brown JC (1978) Interactions of gastric inhibitory polypeptide, glucose and arginine on insulin and glucagon secretion from the perfused rat pancreas. Endocrinology 103: 610-616

9. Schauder P, Brown JC, Frerichs H, Creutzfeldt W (1975) Gastric inhibitory polypeptide: effect on glucose-induced insulin release from isolated rat pancreatic islets in vitro. Diabetologia 11: 483-484

10. Szechowka J, Grill V, Sandberg E, Effendic S (1982) Effect of GIP on the secretion of insulin and somatostatin and the accumulation of cyclic AMP in vitro in the rat. Acta Endocrinol (Copenh) 99: 416-421

11. Schäfer R, Schatz. H(1979) Stimulation of (pro-)insulin biosynthe- sis and release by gastric inhibitory polypeptide in isolated islets of rat pancreas. Acta Endocrinol (Copenh) 91: 493-500

12. Wollheim CB, Sharp GWG (1981) The regulation of insulin release by calcium. Physiol Rev 61:914-973

13. Hedeskov CJ (1980) Mechanism of glucose-induced insulin secretion. Physiol Rev 60: 442-509

14. Lacy PE, Kostianousky M (1967) Method for the isolation of intact islets of Langerhans from the rat pancreas. Diabetes 16:35-39

15. Wollheim CB, Kikuchi M, Renold AE, Sharp GWG (1978) The roles of intracellular and extracellular $\mathrm{Ca}^{\text {th }}$ in glucose-stimulated biphasic insulin release by rat islets. J Clin Invest 61: 451-458

16. Siegel EG, Wollheim CB, Kikuchi M, Renold AE, Sharp GWG (1980) Dependency of cyclic AMP-induced insulin release on intra- and extracellular calcium in rat islets of Langerhans. J Clin Invest $65: 233-241$

17. Herbert V, Lau K-S, Gottlieb CB, Bleicher SJ (1965) Coatedcharcoal immunoassay of insulin. J Clin Endocrinol 25: 1375-1384

18. Cailla HL, Racine-Weisbuch MS, Delaage MA (1973) Adenosine $3^{\prime}, 5^{\prime}$ cyclic monophosphate assay at $10^{-15}$ mole level. Anal Biochem 56: 394-397

19. Ebert R, Illmer K, Creutzfeldt W (1979) Release of gastric inhibitory polypeptide (GIP) by intraduodenal acidification in rats and humans and abolishment of the incretin effect by GIP-antiserum in rats. Gastroenterology 76:515-523

20. Siegel EG, Wollheim CB, Renold AE, Sharp GWG (1980) Evidence for the involvement of $\mathrm{Na} / \mathrm{Ca}$ exchange in glucose-induced insulin release from rat pancreatic islets. J Clin Invest 66: 996-1003

21. Siegel EG, Wollheim CB, Janjic D, Ribes G, Sharp GWG (1983) Involvement of $\mathrm{Ca}^{++}$in the impaired glucose-induced insulin release from islets cultured at low glucose. Diabetes 32:993-1000

22. Rabinovitch A, Cuendet GS, Sharp GWG, Renold AE, Mintz DH (1978) Relation of insulin release to cyclic AMP content in rat pancreatic islets maintained in tissue culture. Diabetes 27: $766-773$

23. Turcot-Lemay L, Lemay A, Lacy PE (1975) Somatostatin inhibition of insulin release from freshly isolated and organ cultured rat islets of Langerhans in vitro. Biochem Biophys Res Commun 63: $1130-1137$

24. Mazzaferri EL, Ciofalo L, Waters LA, Starich GH, Groshong JC, De Palma L (1983) Effects of gastric inhibitory polypeptide on leucine- and arginine-stimulated insulin release. Am J Physiol 245: $114-120$

25. Frandscn FK, Moody AJ (1980) Glucagon, GIP, VIP and secretin activation of mouse islet adenylate cyclase. Diabetologia 19: 274 (Abstract)

26. Malaisse WJ, Herchuelz A, Devis G, Somers G, Boschero AC, Hutton JC, Kawazu S, Sener A, Atwater IJ, Duncan R, Ribalet B, Rojas E (1978) Regulation of calcium fluxes and their regulatory roles in pancreatic islets. In: Calcium transport and cell function. Scarpa A, Carafoli E (eds) Ann NY Acad Sci 307: 562-582

27. Wollheim CB, Siegel EG, Kikuchi M, Renold AE, Sharp GWG (1980) The role of extracellular $\mathrm{Ca}^{++}$and islet calcium stores in the regulation of biphasic insulin release. In: Malaisse W, Pfeiffer EF (eds). Biochemistry and biophysics of the pancreatic Bcell. European Workshop, Brussels. Thieme, Stuttgart 1979, pp 108-115

28. Valverde I, Vandermeers A, Anjaneyulu R, Malaisse W (1979) Calmodulin activation of adenylate cyclase in pancreatic islets. Science 206: 225-227

29. Sharp GWG, Wiedenkeller DE, Kaelin D, Siegel EG, Wollheim CB (1980) Stimulation of adenylate cyclase by $\mathrm{Ca}^{++}$and calmodulin in rat islets of Langerhans. Explanation for the glucose-induced increase in cyclic AMP levels. Diabetes 29:74-77

Received: 7 June 1985, and in revised form: 9 September 1985

Dr. E. G. Siegel

Zentrum Innere Medizin, Georg-August-Universität

Robert-Koch-Str. 40

D-3400 Göttingen, FRG

Nore added in proof. Using this system of cultured islets, it has been shown recently [Schmidt WE, Siegel EG, Creutzfeldt W (1985) Glucagon-like peptide-1 but not glucagon-like peptide-2 stimulates insulin release from isolated rat pancreatic islets. Diabetologia 28: 704-707] that glucagonlike peptide-1 (GLP-1) exerted a GIP-like effect on glucose-induced insulin release. 